\title{
Effect of osmotic predehydration on drying characteristics of banana fruits
}

\author{
Efeito da pré-secagem osmótica sobre as características de banana desidratada
}

\author{
Vahideh Ranemaye Rabbani JALALI ${ }^{1 *}$, Narendra NARAIN ${ }^{1}$, Gabriel Francisco da SILVA ${ }^{1}$
}

\begin{abstract}
Osmotic dehydration is considered to be a suitable preprocessing step to reduce the water content of foods. Such products can be dried further by conventional drying processes to lower their water activity and thus extend their shelf life. In this work, banana (Musa sapientum) fruits were initially treated by osmosis by varying several parameters of the processing conditions which included, besides the cutting format (longitudinal and round slices) of the fruit, temperature $\left(28\right.$ and $\left.49^{\circ} \mathrm{C}\right)$, syrup concentration $\left(50,60\right.$ and $\left.67^{\circ} \mathrm{Brix}\right)$, treatment time $(2,4,6,10$, 14,16 and 18 hours), fruit and syrup ratio (1:1,1:2,1:3 and 1:4) and agitation effects. The best quality products were obtained by the use of the $67^{\circ}$ Brix syrup, for 60 minutes of osmotic treatment, at $28^{\circ} \mathrm{C}$, having a fruit and syrup ratio of 1:1 and agitation. The experimental data obtained on reduction in moisture content during the osmotic treatment were correlated with the experimental equation of $\mathrm{M} / \mathrm{Mo}=\mathrm{Ae}(-\mathrm{Kt})$, where $\mathrm{A}$ and $\mathrm{K}$ are the constants which represent the geometry and effective diffusivity of the drying process. This simplified mathematical model correlated well with the experimental results.
\end{abstract}

Keywords: processing; osmosis; optimization; mathematical modeling; drying.

\section{Resumo}

A desidratação osmótica é considerada como uma etapa de pré-processamento para reduzir o teor da umidade em alimentos. Estes produtos poderão ser desidratados pelo processo de secagem convencional para abaixar o teor de umidade em alimentos, e assim aumentar a vida de prateleira destes produtos. Neste trabalho, a desidratação osmótica de banana prata (Musa sapientum) foi estudada. Os ensaios foram realizados nas temperaturas de 28 e $49^{\circ} \mathrm{C}$, com concentração de xarope de 50, 60 e $67^{\circ}$ Brix, tempo de tratamento $(2,4,6,10,14,16$ e 18 horas $)$, proporção de frutas/xarope de 1:1, 1:2, 1:3 e 1:4, e o efeito de agitação do xarope. Os melhores resultados foram obtidos para concentração de xarope: $67^{\circ} \mathrm{Brix}$, tratamento osmótico de 60 minutos, proporção de fruta/xarope: 1:3, temperatura de $28^{\circ} \mathrm{C}$ e com agitação do xarope. Os dados experimentais da redução da umidade durante a exposição com xarope foram ajustados a um modelo simplificado de dois parâmetros: $\mathrm{U} / \mathrm{Uo}=\mathrm{A} \cdot \exp (-\mathrm{Kt})$, em que A é uma constante que depende da geometria do meio de secagem e K é a constante de secagem que depende da difusividade efetiva do meio de secagem. O modelo matemático simplificado corelatou bem os resultados experimentais.

Palavras-chave: processamento; osmose; otimização; modelamento matemático; secagem.

\section{Introduction}

Banana (Musa sp.) is one of the largely consumed tropical fruits in the world. In the year 2005, the world production of this fruit was 67 million tons. Brazil stood at second place after India contributing to $9 \%$ of the total production (FAO, 2006). Banana is also a fruit of high nutritional value, being rich in starch and sugars, besides vitamins $\mathrm{A}, \mathrm{C}$ and minerals such as potassium, phosphorus, calcium, sodium and magnesium (BORGES, 1997).

Several possibilities of banana dehydration exist, including the use of solar energy and more sophisticated equipments such as the lyophilizer (freeze-dryer) and microwaves. One of the methods used is that of an osmotic pretreatment, followed by dehydration in a cabinet dryer, either under forced air circulation or under vacuum. This method consists of partial removal of water under osmotic pressure, when the food is kept in contact with hypertonic solutes, which consequently decrease water activity and hence increase food stability.
Various researchers (BRANDÃO, 2003; FALCONE; SUAZO, 1988; PAER; RICHBERG, 1998) recommend drying including osmotic dehydration as an important process which helps in water removal by gradient differential and promotes the interaction between the osmotic agent and other compounds which reduce its chemical and biological deterioration. Due to the concentration difference between the osmotic agent and the fruit, two simultaneous flows are created in counter-current through the cell walls, one of water which moves to the solution and the other of solute (sugar or salt) from the solution to the fruit. According to Barbosa-Córnovas and Vega Mercado (1996), in osmotic dehydration the migration of solute depends on the selectivity and permeability of the foods, contact time and size of the material. Osmotic dehydration is considered to be an important technological tool for the development of new derived products from fruits, which add value to such products while maintaining their functional properties (TORREGGIANI; BERTOLO, 2001).

Recebido para publicação em 22/3/2006

Aceito para publicação em 21/2/2008 (001700)

'Departamento de Engenharia Química, Universidade Federal de Sergipe - UFS, Av. Marechal Rondon, s/n, Jardim Rosa Elze, CEP 49100-000, São Cristóvão - SE, Brasil, E-mail:vahideh@ufs.br

${ }^{*}$ A quem a correspondência deve ser enviada 
The development of a mathematical model for any process is indispensable for a better understanding of the mechanisms involved, as well as for simulation studies. With simulation studies, it is possible to quantify the parameters involved in the model for various operating conditions. Depending on the systems, these models which already exist in literature could be adopted for particular studies. One equation which is frequently utilized for drying is given as follows (Equation 1):

$$
\frac{\mathrm{M}-\mathrm{Me}}{\mathrm{Mo}-\mathrm{Me}}=\mathrm{A} \exp (-\mathrm{Kt})
$$

where $M$ is the moisture content (\%) of the sample at time $t ; M o$ is the initial moisture content (\%) of the sample and $M e$ is the equilibrium moisture content (\%) of the sample at the end of drying. A is a constant which depends on the geometry of the sample to be dried and $\mathrm{K}$ is a drying constant which is specific for the diffusivity and length characteristic of the material and it is normally dependent on temperature.

Equation 1 has been utilized by various researchers in drying processes. However, more complex studies on drying are carried out taking into account more terms, whereby permitting results to be much more precise and adjusted to experimental data with minimum deviations. In this work, the objective was to study the effect of syrup concentration, temperature, fruit/syrup proportion and agitation on the moisture content of banana during osmotic dehydration, as well as to verify the application of a suitable mathematical model for drying behavior.

\section{Materials and methods}

\subsection{Materials}

Half ripe banana fruits of the Prata variety (Musa sapientum L.) were acquired from the Safaieh farm, located in the city of São Cristovão, in the state of Sergipe, Brazil. The fruits were left to ripen at ambient temperature and were used only after attaining a yellow color without any black spots. The two forms of sugar utilized for osmotic treatment were granulated and in powder form.

\subsection{Dehydration conditions and modeling}

Bananas were washed in running water, later immersed in chlorinated ( $20 \mathrm{ppm}$ available chlorine) water for 5 minutes and washed again in running water. In preliminary experiments, the type of cut of bananas was standardized. Bananas were cut in two formats - longitudinal and round slices, both of $0.9 \mathrm{~cm}$ thickness. The fruit pieces were immersed in the sugar syrup of $67^{\circ} \mathrm{Brix}$, being this the maximum concentration which could be obtained at ambient temperature $\left(29 \pm 2^{\circ} \mathrm{C}\right)$. Moisture loss was determined at intervals of 2, 5, 8, 10 and 20 hours.

In order to study the effect of sugar syrup concentrat ion at different temperatures $\left(28\right.$ and $49^{\circ} \mathrm{C}$ ), three sugar concentrations (50, 60 and $67^{\circ} \mathrm{Brix}$ ) were tested. Moisture loss was determined at intervals of 2, 4, 6, 10,14, 16 and 18 hours.

To study the effect of the fruit/syrup proportion, the banana slices were kept in the sugar syrup ( $\left.67^{\circ} \mathrm{Brix}\right)$ in fruit/syrup pro- portions of $1: 1 ; 1: 2 ; 1: 3$ and 1:4. Moisture loss was determined at intervals de 2, 5, 8, 10 and 18 hours.

The effect of agitation was evaluated by treating the banana slices with $67^{\circ}$ Brix syrup, having a fruit/syrup proportion of 1:1 for 2, 6 and 8 hours, in two conditions: with and without agitation.

The moisture content was determined in an oven at $70^{\circ} \mathrm{C}$, under vacuum (AOAC, 2000). All the samples of banana partially dehydrated by osmosis were finally dehydrated using a cabinet dryer (Fabbe-Primar, Model 170), equipped with forced air circulation, for 6 hours, when the quality of the dried product was considered to be optimum.

For the adjustment of the drying behavior of the bananas, the equilibrium moisture content could be disregarded in relation to the initial moisture content (dry basis). Thus Equation 1, for the kinetic adjustment of drying, was used in the following form (Equation 2):

$$
\frac{M}{M o}=A \cdot \operatorname{Exp}(-K t)
$$

\subsection{Sensorial analysis}

Sensorial tests were performed in standardized individual cabins possessing adequate illumination. Banana samples were served in individual plates, codified with a three-digit number, to 34 untrained panelists which were composed of students and university employees (being 19 men and 15 women). The samples were evaluated using a preference test based on a nine-point hedonic scale $(9=$ like extremely and $1=$ dislike extremely), wherein appearance and taste attributes were measured.

\subsection{Statistical analysis}

The results were evaluated by analysis of variance (ANOVA) and comparison of mean values by Tukey's test, applied at $5 \%$ level of significance $(\mathrm{p}<0.05)$, using the statistical program SAS (1993).

\section{Results and discussion}

Table 1 presents the data obtained for the moisture content of banana slices in the two formats. There was a significant difference $(\mathrm{p}<0.05)$ in the acceptance test of the two products and dehydrated banana cut in round slices was preferred. The advantage of round slices was in maintaining the uniformity of the product, while for the longitudinal format, it was a greater integrity of the banana fruit. In a sensorial acceptance test performed in the laboratory on the general appearance and taste attributes of the two formats, a higher score (8.1) was obtained for the bananas cut in round slices as compared to the longitudinal cuts (6.6), resulting in preference for the round format.

Figures 1 and 2 present the osmotic dehydration curves of banana slices at temperatures of 49 and $28^{\circ} \mathrm{C}$, respectively, for the concentrations of 50, 60 and $67^{\circ} \mathrm{Brix}$, for different time treatments. From these results, it was verified that moisture content decreased sharply in the first 6 hours of dehydration, after which the reduction was very slow until the final period of 
18 hours. Thus, 6 hours of osmotic dehydration was considered to be optimum. It was further observed that the dehydration velocity increases with the increase in temperature; however, there is a limit to the increase in temperature so as to avoid browning and aroma loss. Mauro and Menegalli (1995) reported the effect of temperature on moisture loss in banana and concluded that at temperatures lower than $40{ }^{\circ} \mathrm{C}$ loss is very slow, and at temperatures higher than $50^{\circ} \mathrm{C}$, flavor and texture could be affected.

The moisture contents (\% dry basis) of banana slices exposed to syrup concentrations of 50, 60 and $67^{\circ} \mathrm{Brix}$, after 6 hours of treatment, were 84, 82 and $80 \%$, respectively. Comparing Figures 1 and 2, it is observed that during all the period of osmosis in syrup concentrations of 50,60 and $67^{\circ} \mathrm{Brix}$, the reduction of moisture content was much higher at a temperature of $49^{\circ} \mathrm{C}$ in comparison to that of $28^{\circ} \mathrm{C}$.

The effect of syrup concentration on the reduction of moisture content in fruits already demonstrated that the increase in osmotic syrup concentration increases diffusional changes and the osmotic pressure exerted on the fruit cell structure which consequently results in greater moisture reduction in more concentrated solutions. However, syrup concentration is not a critical parameter in the range of 65 to $75^{\circ} \mathrm{Brix}$ (SAS, 1993). Various solutes such as sucrose, lactose, maltodextrin and sodium chloride are known to be efficient for osmosis over $60 \%$ concentration.

Table 2 presents the data of the effect of the fruit/syrup proportion during osmotic dehydration and there was no significant difference $(p<0.05)$ observed in the dehydrated slices among all the proportions tested in this study. Thus, the fruit/ syrup proportion of 1:1 was chosen due to its lower cost.

Figures 3 to 7 show the adjusted models prepared by using the experimental data obtained on osmotic dehydration of banana, standardizing processing parameters, applying Equation 2.

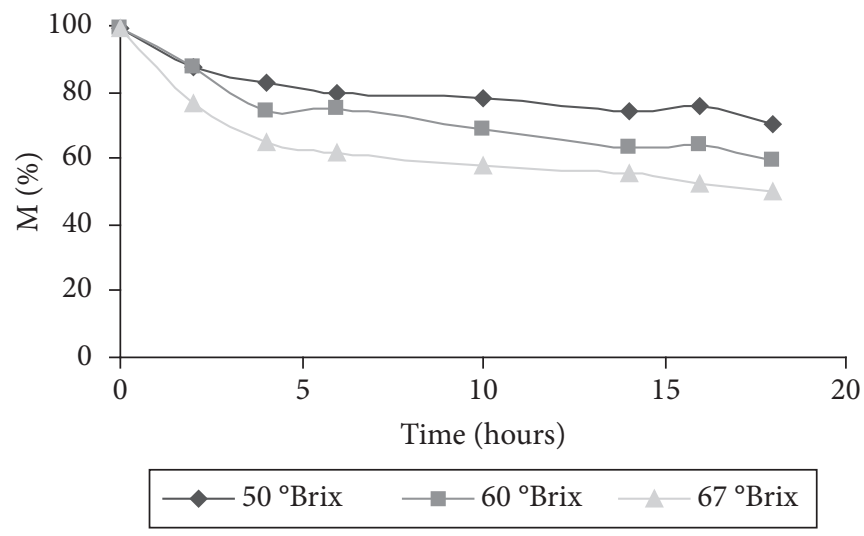

Figure 1. Effect of syrup concentration on moisture content of banana slices at $49^{\circ} \mathrm{C}$.

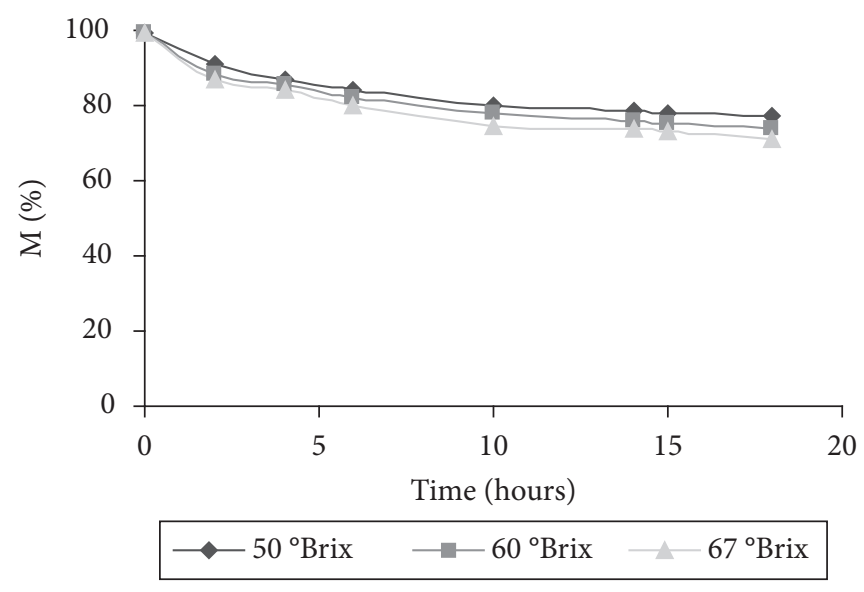

Figure 2. Effect of syrup concentration on moisture content of banana slices at $28^{\circ} \mathrm{C}$.

Table 1. Effect of type of cut on moisture loss in bananas during osmosis and sensorial acceptance scores of the products ${ }^{1}$.

\begin{tabular}{|c|c|c|c|c|c|c|}
\hline \multirow[t]{3}{*}{ Format $^{*}$} & \multicolumn{5}{|c|}{ Average moisture content $(\%)^{\star *}$} & \multirow[t]{2}{*}{ Sensorial acceptance score } \\
\hline & \multicolumn{5}{|c|}{ Treatment time (hours) } & \\
\hline & 2 & 5 & 8 & 10 & 20 & Average \\
\hline Round slices & $58.5 \pm 2.2^{\mathrm{a}}$ & $56.0 \pm 1.8^{\mathrm{a}}$ & $53.0 \pm 1.8^{\mathrm{a}}$ & $50.0 \pm 1.4^{\mathrm{a}}$ & $47.0 \pm 1.2^{\mathrm{a}}$ & $8.1 \pm 0.6^{\mathrm{a}}$ \\
\hline Longitudinal & $57.0 \pm 1.9^{\mathrm{a}}$ & $54.0 \pm 1.6^{\mathrm{a}}$ & $51.5 \pm 1.5^{\mathrm{a}}$ & $48.5 \pm 1.3^{\mathrm{a}}$ & $45.5 \pm 1.1^{\mathrm{a}}$ & $6.6 \pm 0.7^{\mathrm{b}}$ \\
\hline
\end{tabular}

${ }^{1}$ Means in each column followed by different superscript letters were significantly different $(\mathrm{p}<0.05)$; ${ }^{\star}$ Initial moisture content of banana $=66 \%$, Thickness of slice varying from 8 to $10 \mathrm{~mm}$; Syrup concentration $=67^{\circ} \mathrm{Brix}$; Fruit $/$ syrup proportion $=1: 3$; Temperature $=28^{\circ} \mathrm{C}$; and ${ }^{* *}$ Mean values of 3 repetitions.

Table 2. Effect of fruit/syrup proportion during osmosis ${ }^{1}$.

\begin{tabular}{|c|c|c|c|c|c|c|}
\hline \multirow[t]{3}{*}{ Fruit/syrup proportion* } & \multicolumn{5}{|c|}{ Average moisture content $(\%)^{\star *}$} & \multirow{3}{*}{$\begin{array}{c}\text { Sensorial acceptance score } \\
\text { Average } \\
\end{array}$} \\
\hline & \multicolumn{5}{|c|}{ Treatment time (hours) } & \\
\hline & 2 & 5 & 8 & 10 & 20 & \\
\hline $1: 1$ & $61.2 \pm 2.6^{\mathrm{a}}$ & $57.0 \pm 2.0^{\mathrm{a}}$ & $56.0 \pm 1.8^{\mathrm{a}}$ & $53.4 \pm 1.6^{\mathrm{a}}$ & $50.0 \pm 1.3^{\mathrm{a}}$ & $7.9 \pm 0.8^{\mathrm{a}}$ \\
\hline $1: 3$ & $58.9 \pm 2.2^{\mathrm{b}}$ & $56.0 \pm 1.7^{\mathrm{a}}$ & $54.4 \pm 1.6^{\mathrm{b}}$ & $51.5 \pm 1.5^{\mathrm{a}}$ & $48.6 \pm 1.2^{\mathrm{a}}$ & $7.8 \pm 0.8^{\mathrm{a}}$ \\
\hline $1: 4$ & $58.2 \pm 2.2^{\mathrm{b}}$ & $55.7 \pm 1.8^{\mathrm{a}}$ & $53.5 \pm 1.4^{\mathrm{b}}$ & $49.4 \pm 1.4^{\mathrm{b}}$ & $46.0 \pm 1.1^{\mathrm{b}}$ & $7.7 \pm 0.7^{\mathrm{a}}$ \\
\hline
\end{tabular}

${ }^{1}$ Means in each column followed by different superscript letters were significantly different $(\mathrm{p}<0.05)$; ${ }^{\star}$ Initial moisture content of banana $=69.2 \%$; Syrup concentration $=67{ }^{\circ}$ Brix Temperature $=28^{\circ} \mathrm{C} ;{ }^{* *}$ Mean values of 3 repetitions; and ${ }^{* * *}$ For samples subjected to 10 hours of osmotic treatment. 


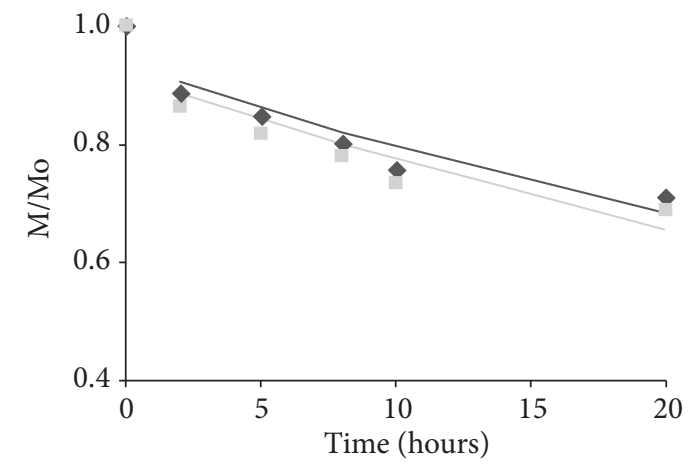

- Round cuts $\backsim$ Longitudinal cuts —Adjusted model

Figure 3. Effect of type of cut on bananas during osmosis.

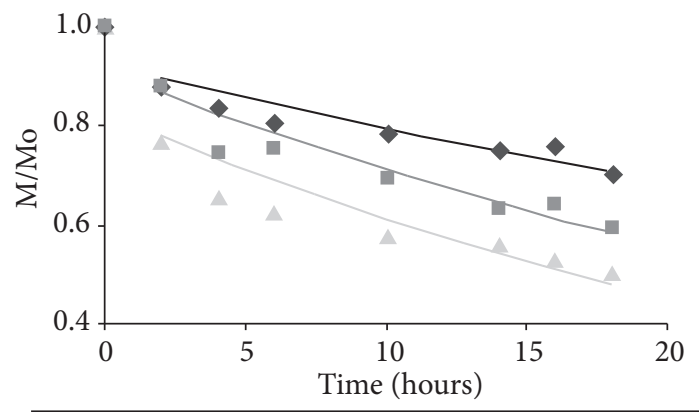

$50^{\circ}$ Brix $\triangle 60^{\circ}$ Brix $\triangle 67^{\circ}$ Brix —Adjusted model

Figure 4. Effect of syrup concentration, at $49^{\circ} \mathrm{C}$, on bananas during osmosis.

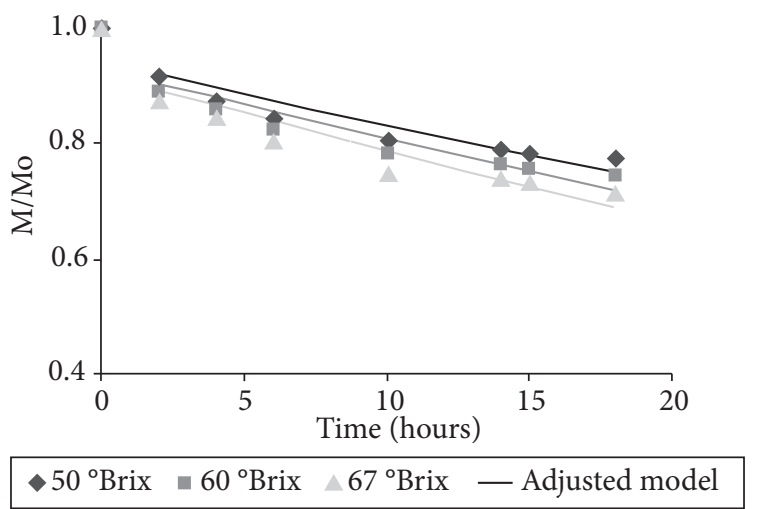

Figure 5. Effect of syrup concentration, at $28^{\circ} \mathrm{C}$, on bananas during osmosis.

As shown in Figures 3 to 7, the experimental data presented in these curves adjusts well to the model data reported on osmotic dehydration of banana. Table 3 presents the data for the various adjusted parameters for the different studies on osmotic dehydration. It is observed that coefficient $\mathrm{K}$, which represents the decrease in moisture content, is much lower in the optimized condition of each parameter. Coefficient $\mathrm{K}$ varied with the variation in ${ }^{\circ} \mathrm{Brix}$ of the solution and consequently the drying rate increased with the increase in sugar concentration. The highest values of $\mathrm{R}^{2}$ were obtained in the evaluation of the

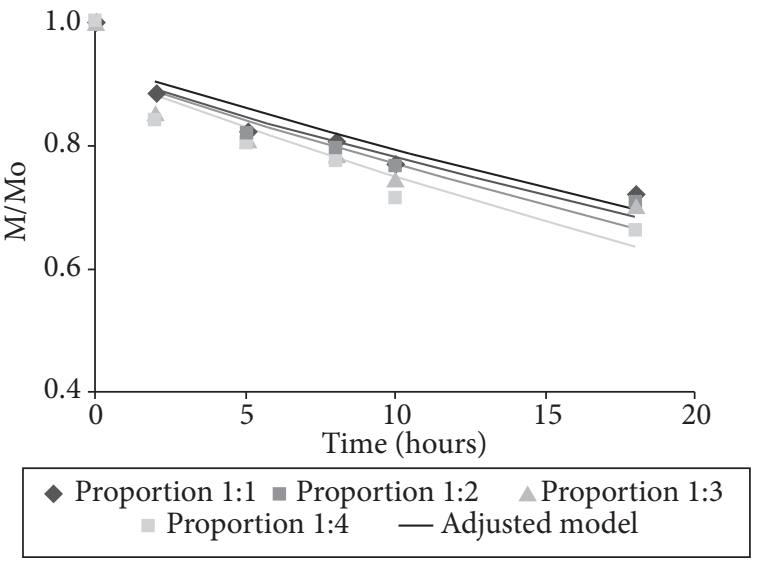

Figure 6. Effect of fruit/syrup proportion during osmosis.

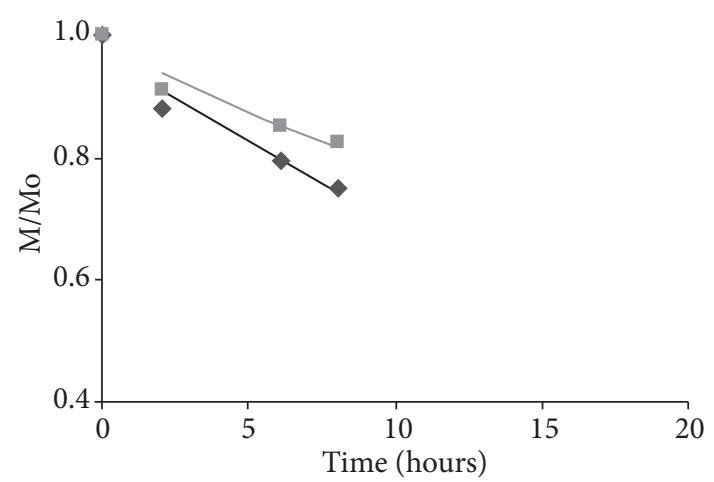

With agitation $\square$ Without agitation — Adjusted model

Figure 7. Effect of agitation during osmosis.

Table 3. Drying parameters adjusted according to Equation 2.

\begin{tabular}{|c|c|c|c|}
\hline Effects ${ }^{*}$ & A & $\mathrm{K}$ & $\mathrm{R}^{2}$ \\
\hline \multicolumn{4}{|c|}{ Effect of cutting format } \\
\hline Round slices & $0.9424^{\mathrm{a}}$ & $0.0127^{\mathrm{a}}$ & $0.8707^{\mathrm{a}}$ \\
\hline Longitudinal cuts & $0.9316^{\mathrm{a}}$ & $0.0143^{\mathrm{a}}$ & $0.8723^{\mathrm{a}}$ \\
\hline \multicolumn{4}{|c|}{ Effect of syrup concentration at $28^{\circ} \mathrm{C}$} \\
\hline $50^{\circ} \mathrm{Brix}$ & $0.9424^{\mathrm{a}}$ & $0.0127^{\mathrm{a}}$ & $0.8707^{\mathrm{a}}$ \\
\hline $60^{\circ}$ Brix & $0.9316^{\mathrm{a}}$ & $0.0143^{\mathrm{a}}$ & $0.8723^{\mathrm{a}}$ \\
\hline $67^{\circ}$ Brix & $0.9234^{\mathrm{a}}$ & $0.0162^{\mathrm{a}}$ & $0.8664^{\mathrm{a}}$ \\
\hline \multicolumn{4}{|c|}{ Effect of syrup concentration at $49^{\circ} \mathrm{C}$} \\
\hline $50^{\circ}$ Brix & $0.9222^{\mathrm{a}}$ & $0.0149^{\mathrm{a}}$ & $0.8457^{\mathrm{a}}$ \\
\hline $60^{\circ}$ Brix & $0.9075^{\mathrm{a}}$ & $0.0245^{\mathrm{a}}$ & $0.8857^{\mathrm{a}}$ \\
\hline $67^{\circ} \mathrm{Brix}$ & $0.8284^{\mathrm{a}}$ & $0.0302^{\mathrm{b}}$ & $0.8131^{\mathrm{b}}$ \\
\hline \multicolumn{4}{|c|}{ Effect of fruit/syrup proportion } \\
\hline $1: 1$ & $0.9328^{\mathrm{a}}$ & $0.0162^{\mathrm{a}}$ & $0.8533^{\mathrm{a}}$ \\
\hline $1: 2$ & $0.9163^{\mathrm{a}}$ & $0.0161^{\mathrm{a}}$ & $0.8041^{\mathrm{b}}$ \\
\hline $1: 3$ & $0.9160^{\mathrm{a}}$ & $0.0175^{\mathrm{a}}$ & $0.8123^{\mathrm{b}}$ \\
\hline $1: 4$ & $0.9166^{\mathrm{a}}$ & $0.0202^{\mathrm{a}}$ & $0.8537^{\mathrm{a}}$ \\
\hline \multicolumn{4}{|c|}{ Effect of agitation } \\
\hline With agitation & $0.9749^{\mathrm{a}}$ & $0.03375^{\mathrm{a}}$ & $0.9611^{\mathrm{a}}$ \\
\hline Without agitation & $0.9791^{\mathrm{a}}$ & $0.02268^{\mathrm{b}}$ & $0.9416^{\mathrm{a}}$ \\
\hline
\end{tabular}

${ }^{*}$ Means in each column followed by different superscript letters were significantly different $(\mathrm{p}<0.05)$. 
effect of mixing. However, in relation to constant A, no significant variation was observed with the variation in ${ }^{\circ}$ Brix or in fruit/syrup proportion. In a similar study performed earlier by Borges and Menegalli (1994), on mango initially dehydrated by osmotic treatment, the authors also supported the applicability of the equation for kinetic evaluation of the drying process.

\section{Conclusions}

Although better results for moisture loss in bananas with osmotic treatment were obtained when osmosis was carried out using sugar syrup at $48^{\circ} \mathrm{C}$, the dehydrated banana slices obtained with the use of $67^{\circ}$ Brix sugar syrup at ambient temperature $\left(28 \pm 1^{\circ} \mathrm{C}\right)$, for 60 minutes of osmotic treatment, having a fruit/syrup proportion of $1: 1$ and agitation was preferred and a simplified mathematical model, using the experimental equation of $\mathrm{M} / \mathrm{Mo}=\mathrm{Ae}(-\mathrm{Kt})$ fitted well to the experimental results.

\section{References}

AOAC. Association of Official Analytical Chemists. Official Methods of Analysis. 17 $7^{\text {th }}$ ed., 2000.

BARBOSA-CÁNOVAS, G.V.; VEGA-MERCADO, H. Dehydration of Foods. Boca Raton: International Thomson Publishing, Chapman \& Hall, 1996. p. 265-281.

BORGES, S. V.; MENEGALLI, F. C. Influência da desidratação osmótica sobre a cinética da secagem de manga. Pesquisa Agropecuária Brasileira, Brasilia, v. 29, n. 4, p. 637-642, 1994.
BORGES, A. L. et al. O Cultivo da Banana. EMBRAPA - CNPMF. Circular Técnica v. 27, p. 109. Cruz das Almas: EMBRAPA CNPMF, 1997.

BRANDÃO, M. C. C. et al. Análises físico-químicas, microbiológicas e sensoriais de pedúnculos de caju submetidos a desidratação osmótico-solar. Revista Ciência Agronômica, Fortaleza, v. 34, n. 2, p. 139-145, 2003.

FALCONE, M. A.; SUAZO, V. A. T. Desidratação osmótica do abacaxi (Ananas comosus L.). Parte I. Boletim da SBCTA, Campinas, v. 22, n. 1/2, p. 17-35, 1988.

FAO. Food and Agriculture Organization. FAOSTAT Database. [online] 2006. Disponível em: $<$ http//faostat.fao.org $>$. Acesso em: 27 jan. 2007.

MAURO, M. A.; MENEGALLI, F. Evaluation of diffusion coefficients in osmotic concentration of banana (Musa Cavendish Lambert). International Journal of Food Science and Technology, New Jersey, v. 30, n. 2, p. 199-213, 1995.

PAER, M.; RICHBERG, C. G. Process for preparing dehydrated fruits. U.S. Patent 3.365.309, 1998.

SAS Institute. SAS user's guide: statistics. Cary, USA: SAS Institute. 1993.

SOUSA, P. H. M. et al. Influência da concentração e da proporção fruto: xarope na desidratação osmótica de banana processada. Ciência e Tecnologia de Alimentos, Campinas, v. 23, (Supl.), p. 126-130, 2003.

TORREGGIANI, D.; BERTOLO, G. Osmotic treatments in fruit processing: chemical, physical and structural effects. Journal of Food Engineering, Oxford, v. 49, n. 2-3, p. 247-256, 2001. 